\title{
Effects of a rumen protected B vitamin blend substituted for biotin upon milk production and component yield in lactating dairy cows
}

\author{
Essi Evans $^{1^{*}}$, David T. Mair ${ }^{2}$ \\ ${ }^{1}$ Essi Evans Technical Advisory Services Inc., Bowmanville, Canada; \\ *Corresponding Author: essievans@sympatico.ca \\ ${ }^{2}$ Jefo Nutrition Inc., Quebec, Canada
}

Received 17 January 2013; revised 23 February 2013; accepted 27 March 2013

Copyright (C) 2013 Essi Evans, David T. Mair. This is an open access article distributed under the Creative Commons Attribution License, which permits unrestricted use, distribution, and reproduction in any medium, provided the original work is properly cited.

\section{ABSTRACT}

Results from 4 switchback field trials involving 608 cows were combined to assess the effects of a protected B vitamin blend (BVB) vs $10 \mathrm{mg}$ of unprotected biotin upon milk yield $(\mathrm{kg})$, fat \%, protein \%, fat yield $(\mathbf{k g})$ and protein yield $(\mathrm{kg})$ in primiparous and multiparous cows. Trials consisted of 3 DHIA periods executed in the order control-test-control. Cows from 45 to 300 days in milk (DIM) at the start of the experiment that were available for all 3 periods were included in the analysis. No diet changes other than the substitution of 3 grams/cow/day of the BVB for $10 \mathrm{mg}$ of biotin during the test period occurred. Results from the two control periods were compared to results obtained during the test period by individual cow using a paired $T$ test. Results for all cows showed that the provision of the BVB resulted in increased $(P<0.05)$ milk, fat percentage (\%), protein $\%$, fat yield and protein yield. Analysis by age revealed that milk production and milk protein yield were only improved in mature cows. Milk production had a negative effect upon the magnitude of the increase in milk components. The change in milk yield was greatest in early lactation and declined with DIM. Protein \% and fat \% increased with DIM in mature cows, but not in first lactation cows. Differences in fat yields between test and control feeding periods did not change with DIM, but the improvement in protein yield in mature cows declined with DIM. These results indicate that the BVB provided economically important advantages throughout lactation beyond those witnessed with biotin, but expected results would vary with cow age and stage of lactation.

Keywords: B Vitamin Blend; Biotin; Milk Components

\section{INTRODUCTION}

Biotin is a noteworthy B vitamin for dairy cows, particularly with respect to maintenance of hoof health $[1$, 2]. Biotin has additionally been reported to improve milk production, although this response is less consistent. While being investigated as a tool to improve hoof health, Bergsten et al. [3] found an improvement in milk yield in one long-term experiment. This was attributed to improved locomotion, and the ability to compete for feed in this full lactation evaluation. No production improvements were identified in another study evaluating 10 and $20 \mathrm{mg} /$ cow/day of added biotin [4]. Ferriera et al. [5] showed that supplemental biotin improved milk yield in high producing cows, but did not change yield in low producing cows. This response was rapid, and therefore could not be attributed to improved foot health, which takes a relatively long period of time to change. Zimmerly and Weiss [6] found that milk production and milk protein production increased linearly with the inclusion of 10 or $20 \mathrm{mg}$ of biotin/cow/day in early lactation. Biotin improved milk production in multiparous but not primiparous cows in early lactation in another study [7]. Milk production was not altered in another early lactation study [8], indicating outcome might be related to factors such as yield, DIM or parity.

In an analysis of results from studies testing a protected B vitamin blend (BVB) Evans et al. [9] found that responses to the product were dependent on parity, DIM, and level of production. Results with the BVB could be due to the biotin in the product. Further trials were exe- 
cuted to determine if the results obtained were due to in whole or in part to biotin or if other vitamins in the BVB made a contribution to the results as well. This analysis was conducted to gain insight into differences and similarities in results between the inclusion biotin and the BVB in the diet of lactating dairy cows.

\section{MATERIALS AND METHODS}

Four on-farm feeding experiments were conducted to compare responses to $10 \mathrm{mg} / \mathrm{cow} /$ day of unprotected biotin to a protected BVB (Vicomb $\mathrm{P}^{+\circledR}$, Jefo Nutrition Inc., St. Hyacinthe, QC) fed at 3 grams/head/day that likewise provided $10 \mathrm{mg} / \mathrm{cow} /$ day of biotin, along with folic acid, pantothenic acid and pyridoxine. A complete description of the product was provided by Sacadura et al. [10]. Cows were provided with a consistent diet for 3 consecutive feeding periods. Feeding periods were defined as the length of time between Dairy Herd Improvement Association (DHIA) milk tests from herds on a monthly, twice-daily testing program. The only feed change that was permitted was the substitution of $10 \mathrm{mg}$ of biotin with 3 grams of a protected BVB. Both the biotin and the BVB were mixed into the concentrate portion of the total mixed ration based upon the average daily dry matter intake of the lactating cows on each farm.

Individual cow records were used in the analyses. Cows selected for participation in the study were those that been on a consistent diet for at least 21 days before the first DHIA test, were at least 45 days and no more than 300 days in milk (DIM) at the first test date and were available for all three testing periods. Milk yield $(\mathrm{kg})$, milk fat $\%$, milk protein $\%$, milk fat yield $(\mathrm{kg})$ and milk protein yield $(\mathrm{kg})$ were monitored by cow. Data from the 4 individual trials were combined for the final analysis.

Data were made available from DHIA as comma delineated files and were then transferred into a Microsoft Excel $^{\circledR}$ spreadsheet. Data from period 1 and period 3 were compared by cow to data for period 2 for all variables using a paired, two sided $\mathrm{T}$ test using the data analysis function within Microsoft Excel ${ }^{\circledR}$. Regression models were developed from the data set using Minitab 16 statistical software (Minitab Inc., State College, PA).

\section{RESULTS AND DISCUSSION}

Table 1 provides cow numbers from the 4 participating herds. All herds were producing $30 \mathrm{~kg}$ or more of milk on average.

Milk, fat and protein yields increased $(\mathrm{P}<0.05)$ with the provision of the $\mathrm{B}$ vitamin blend relative to biotin (Table 2) for the dataset in which all cows were included. Although this strongly suggests that the response to the $\mathrm{BVB}$ is not due solely to the biotin that the product pro-
Table 1. Description of data used in the analyses.

\begin{tabular}{ccccc}
\hline Farm & Country & $\begin{array}{c}\text { Cows } \\
\text { milking, } \mathbf{~}\end{array}$ & $\begin{array}{c}\text { Cows } \\
\text { used, } \mathbf{N}\end{array}$ & $\begin{array}{c}\text { Average } \\
\text { yield, kg }\end{array}$ \\
\hline 1 & USA & 140 & 104 & 34 \\
2 & USA & 240 & 216 & 32 \\
3 & USA & 120 & 78 & 32 \\
4 & USA & 300 & 210 & 30 \\
\hline
\end{tabular}

Table 2. Effects of B vitamin supplementation upon lactation performance.

\begin{tabular}{|c|c|c|c|}
\hline Parameter & BVB & Biotin & P-Level \\
\hline \multicolumn{4}{|c|}{ All cows $(\mathrm{N}=608)$} \\
\hline Milk, 1 & 32.1 & 31.42 & $<0.05$ \\
\hline Fat, \% & 3.69 & 3.53 & $<0.05$ \\
\hline Protein, \% & 3.14 & 3.12 & $<0.05$ \\
\hline Fat yield, $\mathrm{kg}$ & 1.17 & 1.10 & $<0.05$ \\
\hline Protein yield, $\mathrm{kg}$ & 1.00 & 0.98 & $<0.05$ \\
\hline \multicolumn{4}{|c|}{ First lactation cows $(\mathrm{N}=191)$} \\
\hline Milk, 1 & 28.1 & 27.9 & 0.57 \\
\hline Fat, \% & 3.80 & 3.67 & $<0.05$ \\
\hline Protein, $\%$ & 3.19 & 3.15 & $<0.05$ \\
\hline Fat yield, kg & 1.06 & 1.02 & $<0.05$ \\
\hline Protein yield, $\mathrm{kg}$ & 0.89 & 0.87 & 0.16 \\
\hline \multicolumn{4}{|c|}{ Cows lactation $\geq 2(\mathrm{~N}=417)$} \\
\hline Milk, 1 & 34.0 & 33.1 & $<0.05$ \\
\hline Fat, $\%$ & 3.64 & 3.47 & $<0.05$ \\
\hline Protein, \% & 3.12 & 3.11 & $<0.05$ \\
\hline Fat yield, $\mathrm{kg}$ & 1.22 & 1.14 & $<0.05$ \\
\hline Protein yield, $\mathrm{kg}$ & 1.05 & 1.02 & $<0.05$ \\
\hline
\end{tabular}

vides and that these herds responded positively to the additional vitamins in the BVB, there were differences in responses that could be associated with lactation number. Results showed that the improvement in milk yield and protein yield occurred in mature cows only, and not in the first lactation cows. When only the BVB was provided [9], primiparous cows produced 0.81 more milk and $0.05 \mathrm{~kg}$ more protein when the BVB was supplied.

The regression of current milk yield on change in milk yield showed lower yielding cows would be more likely to respond to the BVB than higher producing cows (Table 3). This is opposite to the findings with biotin, where only higher producing cows showed greater yields [5].

Milk yield response to the BVB relative to biotin de- 
clined with DIM in mature cows (Table 4). In contrast, milk and protein yield increased in primiparous cows when the BVB was added to rations that had not previously contained biotin [9]. This would suggest that at least part of the response to the BVB is associated with the inclusion of biotin in primiparous cows.

In Contrast, milk yield increased $(\mathrm{P}<0.05)$ in multiparous cows given the BVB, suggesting it is not likely that biotin alone was responsible for the change. Sacadura et al. [10] calculated that the B vitamins likely to be deficient in lactating dairy cows would be pantothenic acid, pyridoxine, and folic acid, but that biotin was less likely to be limiting. However, microbial production of biotin is closely related to ration forage levels [11], and may explain the positive results to inclusion found in other experiments $[3,5,6]$ where forages levels were moderate.

Two past studies $[9,10]$ showed the inclusion of the $\mathrm{BVB}$ in the diet of lactating cows was instrumental in increasing milk fat \% and total yield. Such effects have not been reported with biotin, and may therefore be due to one or more of the other vitamins in the BVB. Milk fat $\%$ and yield increased in primiparous and multiparous cows in this study when cows received the BVB, relative to biotin alone.

Ferreira et al. [5] found that biotin improved milk production in high producing but not low producing cows. Similar results were anticipated in the current study with the BVB, but there were notable differences. In Table 4, the regression model predicting the effects of current milk yield on the change in milk yield obtained with the vitamin blend revealed that cows in lactation 2 or higher responded regardless of production level, while first lactation cows were more likely to respond to the added B vitamin if their level of production was low, quite the opposite of the findings of Ferreira et al. [5]

Table 3. Effects of current milk yield on change in milk yield when a B vitamin blend replaced $10 \mathrm{mg}$ of biotin for lactating cows.

\begin{tabular}{ccccc}
\hline Group & Intercept & Slope & $\mathrm{R}^{2}$ & P-Level \\
\hline All cows & 5.97 & -0.148 & 5.4 & $<0.05$ \\
First lactation & 11.8 & -0.417 & 24.1 & $<0.05$ \\
Lactation $\geq 2$ & 6.73 & -0.160 & 4.5 & $<0.05$ \\
\hline
\end{tabular}

Table 4. Effect of days in milk on change in milk yield when a $\mathrm{B}$ vitamin blend replaced $10 \mathrm{mg}$ of biotin for lactating cows.

\begin{tabular}{ccccc}
\hline Group & Intercept & Slope & $\mathrm{R}^{2}$ & P-Level \\
\hline All cows & 1.84 & -0.00967 & 3.0 & $<0.05$ \\
First lactation & 0.935 & -0.00612 & 1.5 & 0.10 \\
Lactation $\geq 2$ & 2.25 & -0.0112 & 3.7 & $<0.05$ \\
\hline
\end{tabular}

with biotin alone.

Milk production declines as lactation advances. The difference in milk yield response to the BVB between test and control periods was significantly reduced by DIM for mature cows (Table 5), showing milk increases occur in early stages of lactation. However, the regression model indicates that heifers are more likely to sustain a response to the BVB throughout their lactation. Table 5 provides predictions of response when both yield and DIM are included in the regression. When the effects of DIM were taken into account, yield clearly had a significant negative impact on the change in milk yield with the BVB.

As noted, the BVB supported greater milk fat $\%$ than did supplemental biotin. Equations provided in Table 6 demonstrate that the improvement in fat $\%$ when the BVB was supplied to cows would likely not be witnessed in primiparous or multiparous cows producing more than $4 \%$ fat. Interestingly, the BVB appears to support higher milk fat $\%$ when milk fat $\%$ values are low.

In general, milk fat $\%$ tends to be lower in high producing cows. Fat percentages are most often lower in early lactation, and increase as lactation advances. The increase in milk fat \% in these trials could not $(\mathrm{P}>0.05)$ be related to milk yield (Table 7) or to DIM (Table 8).

Findings were similar with milk protein \%. Greater protein $\%$ values seen with the BVB relative to biotin would only be anticipated to occur when current milk protein \% was below approximately 3.20\% (Table 9). It is possible that the response declines as the genetic potential for milk protein is approached [11]. The BVB positively influenced protein $\%$ as milk production increased in primiparous, but not in multiparous cows (Table 10). Changes in protein $\%$ could not be related to DIM (Table 11).

The primiparous cows are still growing, and depositing protein in tissue. It is possible that one of the vitamins is asserting an effect on growth, resulting in differences in protein utilization relative to mature cows. The direction of the change in protein with milk production was positive for cows in lactation 1 (Table 10) but negative for cows in lactation 2 or greater. Long term studies would be needed to determine if the BVB improved growth and productive longevity in primiparous cows.

In most dairy marketing schemes, fat and protein yield are the basis for payment, and effective ingredients with the ability to improve yields of fat and protein benefit dairy producers. As Table 4 showed that fat yield was increased in all cows, and protein yield was improved in first lactation cows with the BVB relative to biotin. Although fat yield was greater on average with the BVB, the change in fat yield declined with the overall yield of fat (Table 12). This indicates that the BVB holds the greatest advantage over biotin in herds with lower fat 
Table 5. Effects of current milk yield and days in milk on change in milk yield when a B vitamin blend replaced $10 \mathrm{mg}$ of biotin for lactating cows.

\begin{tabular}{ccccccc}
\hline Group & Intercept & Slope yield & P-Level & Slope DIM & P-Level & $\mathrm{R}^{2}$ \\
\hline All cows & 10.1 & -0.236 & $<0.05$ & -0.0165 & $<0.05$ & 12.3 \\
First lactation & 13.2 & -0.429 & $<0.05$ & -0.00816 & $<0.05$ & 26.3 \\
Lactation $\geq 2$ & 13.3 & -0.292 & $<0.05$ & -0.0227 & $<0.05$ & 15.0 \\
\hline
\end{tabular}

Table 6. Effects of current milk fat \% on change in milk fat $\%$ when a $\mathrm{B}$ vitamin blend replaced $10 \mathrm{mg}$ of biotin for lactating cows.

\begin{tabular}{ccccc}
\hline Group & Intercept & Slope & $\mathrm{R}^{2}$ & P-Level \\
\hline All cows & 1.45 & -0.367 & 17.4 & $<0.05$ \\
First lactation & 1.44 & -0.358 & 20.4 & $<0.05$ \\
Lactation $\geq 2$ & 1.48 & -0.379 & 16.5 & $<0.05$ \\
\hline
\end{tabular}

Table 7. Effects of current milk yield on change in milk fat $\%$ when a $\mathrm{B}$ vitamin blend replaced $10 \mathrm{mg}$ of biotin for lactating cows.

\begin{tabular}{ccccc}
\hline Group & Intercept & Slope & $\mathrm{R}^{2}$ & P-Level \\
\hline All cows & 0.249 & -0.0 .00310 & 0.2 & 0.31 \\
First lactation & 0.057 & 0.00662 & 0.6 & 0.76 \\
Lactation $\geq 2$ & 0.410 & -0.00747 & 0.9 & 0.06 \\
\hline
\end{tabular}

Table 8. Effects of days in milk on change in milk fat \% when a B vitamin blend replaced $10 \mathrm{mg}$ of biotin for lactating cows.

\begin{tabular}{ccccc}
\hline Group & Intercept & Slope & $\mathrm{R}^{2}$ & P-Level \\
\hline All cows & 0.125 & 0.000192 & 0.1 & 0.43 \\
First lactation & 0.197 & -0.000555 & 1.1 & 0.16 \\
Lactation $\geq 2$ & 0.930 & 0.000536 & 0.7 & 0.08 \\
\hline
\end{tabular}

Table 9. Effects of current milk protein \% on change in milk protein $\%$ when a B vitamin blend replaced $10 \mathrm{mg}$ of biotin for lactating cows.

\begin{tabular}{ccccc}
\hline Group & Intercept & Slope & $\mathrm{R}^{2}$ & P-Level \\
\hline All cows & 0.683 & -0.214 & 13.0 & $<0.05$ \\
First lactation & 0.715 & -0.217 & 14.4 & $<0.05$ \\
Lactation $\geq 2$ & 0.685 & -0.218 & 13.1 & $<0.05$ \\
\hline
\end{tabular}

Table 10. Effects of current milk yield on change in milk protein $\%$ when a B vitamin blend replaced $10 \mathrm{mg}$ of biotin for lactating cows.

\begin{tabular}{ccccc}
\hline Group & Intercept & Slope & $\mathrm{R}^{2}$ & P-Level \\
\hline All cows & 0.0345 & -0.000655 & 0.1 & 0.50 \\
First lactation & -0.144 & 0.00625 & 4.7 & $<0.05$ \\
Lactation $\geq 2$ & 0.0640 & -0.00174 & 5.0 & 0.15 \\
\hline
\end{tabular}

Table 11. Effects of days in milk on change in milk protein \% when a $\mathrm{B}$ vitamin blend replaced $10 \mathrm{mg}$ of biotin for lactating cows.

\begin{tabular}{ccccc}
\hline Group & Intercept & Slope & $\mathrm{R}^{2}$ & P-Level \\
\hline All cows & 0.00570 & 0.000045 & 0.1 & 0.58 \\
First lactation & 0.0511 & -0.000169 & 1.0 & 0.18 \\
Lactation $\geq 2$ & 0.0144 & 0.000140 & 0.7 & 0.10 \\
\hline
\end{tabular}

Table 12. Effects of current milk fat yield on change in milk fat yield when a B vitamin blend replaced $10 \mathrm{mg}$ of biotin for lactating cows.

\begin{tabular}{ccccc}
\hline Group & Intercept & Slope & $\mathrm{R}^{2}$ & P-Level \\
\hline All cows & 0.512 & -0.402 & 17.9 & $<0.05$ \\
First lactation & 0.635 & -0.583 & 36.1 & $<0.05$ \\
Lactation $\geq 2$ & 0.531 & -0.395 & 16.6 & $<0.05$ \\
\hline
\end{tabular}

Table 13. Effects of current milk yield on change in milk fat yield when a B vitamin blend replaced $10 \mathrm{mg}$ of biotin for lactating cows.

\begin{tabular}{ccccc}
\hline Group & Intercept & Slope & $\mathrm{R}^{2}$ & P-Level \\
\hline All cows & 0.250 & -0.00578 & 2.6 & $<0.05$ \\
First lactation & 0.452 & -0.0147 & 12.7 & $<0.05$ \\
Lactation $\geq 2$ & 0.277 & -0.00594 & 2.5 & $<0.05$ \\
\hline
\end{tabular}

Table 14. Effects of days in milk on change in milk fat yield when a B vitamin blend replaced $10 \mathrm{mg}$ of biotin for lactating cows.

\begin{tabular}{ccccc}
\hline Group & Intercept & Slope & $\mathrm{R}^{2}$ & P-Level \\
\hline All cows & 0.108 & -0.000341 & 1.5 & $<0.05$ \\
First lactation & 0.0869 & -0.000372 & 2.3 & $<0.05$ \\
Lactation $\geq 2$ & 0.118 & -0.000323 & 1.2 & $<0.05$ \\
\hline
\end{tabular}

yields. This effect was also negatively related to level of production (Table 13). Higher fat yields would be expected when milk production is lower than 32 liters. The improvement in fat yield declined with DIM (Table 14). However, fat yield would be expected to be higher with the BVB than with biotin in the diet up until 316 DIM (233 for primiparous and 365 DIM for multiparous 
Table 15. Effects of current milk fat yield and days in milk on change in milk fat yield when a B vitamin blend replaced $10 \mathrm{mg}$ of biotin for lactating cows.

\begin{tabular}{ccccccc}
\hline Group & Intercept & Slope fat yield & P-Level & Slope DIM & P-Level & $\mathrm{R}^{2}$ \\
\hline All cows & 0.599 & -0.421 & $<0.05$ & -0.000547 & $<0.05$ & 20.6 \\
First lactation & 0.647 & -0.574 & $<0.05$ & -0.000175 & $<0.23$ & 36.6 \\
Lactation $\geq 2$ & 0.672 & -0.445 & $<0.05$ & -0.000703 & $<0.05$ & 20.4 \\
\hline
\end{tabular}

Table 16. Effects of current milk protein yield on change in milk protein yield when a B vitamin blend replaced $10 \mathrm{mg}$ of biotin for lactating cows.

\begin{tabular}{ccccc}
\hline Group & Intercept & Slope & $\mathrm{R}^{2}$ & P-Level \\
\hline All cows & 0.306 & -0.289 & 12.5 & $<0.05$ \\
First lactation & 0.444 & -0.491 & 29.0 & $<0.05$ \\
Lactation $\geq 2$ & 0.339 & -0.305 & 12.3 & $<0.05$ \\
\hline
\end{tabular}

Table 17. Effects of current milk yield on change in milk protein yield when a B vitamin blend replaced $10 \mathrm{mg}$ of biotin for lactating cows.

\begin{tabular}{ccccc}
\hline Group & Intercept & Slope & $\mathrm{R}^{2}$ & P-Level \\
\hline All cows & 0.194 & -0.00543 & 5.7 & $<0.05$ \\
First lactation & 0.334 & -0.0115 & 18.6 & $<0.05$ \\
Lactation $\geq 2$ & 0.205 & -0.00534 & 5.1 & $<0.05$ \\
\hline
\end{tabular}

Table 19. Effects of current protein yield and days in milk on change in protein yield when a B vitamin blend replaced 10 mg of biotin for lactating cows.

\begin{tabular}{ccccccc}
\hline Group & Intercept & Slope protein yield & P-Level & Slope DIM & P-Level & $\mathrm{R}^{2}$ \\
\hline All cows & 0.307 & -0.00722 & $<0.05$ & -0.000472 & $<0.05$ & 11.3 \\
First lactation & 0.451 & -0.483 & $<0.05$ & 0.000119 & 0.23 & 29.5 \\
Lactation $\geq 2$ & 0.476 & -0.372 & $<0.05$ & -0.000564 & $<0.05$ & 1.5 \\
\hline
\end{tabular}

Table 18. Effects of days in milk on change in milk protein yield when a B vitamin blend replaced $10 \mathrm{mg}$ of biotin for lactating cows.

\begin{tabular}{ccccc}
\hline Group & Intercept & Slope & $\mathrm{R}^{2}$ & P-Level \\
\hline All cows & 0.0543 & -0.000262 & 2.3 & $<0.05$ \\
$\begin{array}{c}\text { First } \\
\text { lactation }\end{array}$ & 0.0422 & -0.000227 & 2.0 & $<0.05$ \\
Lactation $\geq 2$ & 0.0596 & -0.000277 & 2.4 & $<0.05$ \\
\hline
\end{tabular}

cows). Current fat yield and DIM explained the largest portion of the total variation in milk fat yield (Table 15).

Overall, protein yield increased in mature cows only (Table 4). However, the regression models showed that the BVB changed protein yield in both primiparous and multiparous cows. Table 16 illustrates that the alteration in protein is related to the current amount of protein being produced. If the yield is low in either first lactation or later lactation cows, they are likely to respond to the $\mathrm{BVB}$, with protein output increasing. Relationships were established between changes in protein yield and milk yield. This occurred animals of all age groups (Table 17). The regression models suggested that improvements in protein yield would be expected in mature cows producing less than 381 and first lactation cows producing less than 291 of milk. In similar fashion the change in protein yield with the BVB relative to biotin was influenced by DIM when evaluated alone (Table 18) but not when in- cluded with change in protein yield (Table 19).

Majee et al. [12] compared performances of cows receiving a control ration, a BVB or biotin alone at 20 $\mathrm{mg} /$ day. The BVB provided no advantage over biotin alone. In the current study, the BVB was ruminally protected, and that might account for the differences in results. Santschi et al. [13] clearly demonstrated that B vitamins added to the rumen were largely destroyed by rumen microbes, and this could have negated any benefit in the study conducted by Majee et al. [12].

\section{IMPLICATIONS}

This analysis shows that supplementation of lactating dairy cows with a rumen protected BVB containing biotin, folic acid, pantothenic acid and pyridoxine improved milk yield, fat $\%$, fat yield, and protein yield in multipa rous and primiparous cows, relative to unprotected biotin. Expected response to the BVB would depend upon level of production, current milk composition and stage of lactation. Data provided from this study can be used to predict outcome from the use of the BVB as changes in production level and herd demographics occur.

\section{REFERENCES}

[1] Midla, L.T., Hoblet, K.H., Weiss, W.P. and Moeschberger, M.L. (1998) Supplemental dietary biotin for prevention 
of lesions associated with aseptic subclinical laminitis (pododermatitis aseptica diffusa) in primiparous cows. American Journal of Veterinary Research, 59, 733-738.

[2] Fitzgerald, T., Norton, B.W., Elliott, R., Podlich, H. and Svendsen, O.L. (2000) The influence of long-term supplementation with biotin on the prevention of lameness in pasture fed dairy cows. Journal of Dairy Science, 83, 338-344. doi:10.3168/jds.S0022-0302(00)74884-3

[3] Bergsten, C., Greenough, P.R., Gay, J.M., Seymour, W.H. and Gay, C.C. (2003) Effects of biotin supplementation on performance and claw lesions on a commercial dairy farm. Journal of Dairy Science, 86, 3953-3962. doi:10.3168/jds.S0022-0302(03)74005-3

[4] Ganjkhanlou, M., Salimi, M., Nikkhah, A. and Zali, A. (2007) Effects of supplemental biotin on performance of Holstein dairy cows. Pakistan Journal of Biological Sciences, 10, 2960-2963. doi:10.3923/pjbs.2007.2960.2963

[5] Ferreira, G., Weiss, W.P. and Willet, L.B. (2007) Changes in measures of biotin status do not reflect milk yield responses when dairy cows are fed supplemental biotin. Journal of Dairy Science, 90, 1452-1459. doi:10.3168/jds.S0022-0302(07)71630-2

[6] Zimmerly, C.A. and Weiss, W.P. (2001) Effects of supplemental dietary biotin on performance of Holstein cows during early lactation. Journal of Dairy Science, 84, 498506. doi:10.3168/jds.S0022-0302(01)74500-6

[7] Enjalbert, F., Nicot, M.C. and Packington, A.J. (2008) Effect of peripartum biotin supplementation of dairy cows on milk production and milk composition with emphasis on fatty acid profile. Livestock Science, 114, 287295. doi:10.1016/j.livsci.2007.05.013
[8] Rosendo, O., Staples, C.R., McDowell, L.R., McMahon, R., Badinga, L., Martin, L.G., et al. (2004) Effects of biotin supplementation on peripartum performance and metabolites of Holstein cows. Journal of Dairy Science, 87, 2535-2545. doi:10.3168/jds.S0022-0302(04)73378-0

[9] Evans, E. and Mair, D.T. (2013) Effects of a rumen protected B vitamin blend upon milk production and component yield in lactating dairy cows. Open Journal of Animal Sciences, 3, 76-82. doi:10.4236/ojas.2013.31011

[10] Sacadura, F.C., Robinson, P.H., Evans, E. and Lordelo, M. (2008) Effects of a ruminally protected B-vitamin supplement on milk yield and composition of lactating dairy cows. Animal Feed Science and Technology, 144, 111124. doi:10.1016/j.anifeedsci.2008.06.004

[11] Dacosta-Gomez, C., Masri, M.A., Steinberg, W. and Abel, J.J. (1998) Effect of varying hay/barley proportions on microbial biotin metabolism in the rumen simulating fermenter Rusitec. Proceedings of the Society of Nutritional Physiology, 7, 30.

[12] Majee, D.N., Schwab, E.C., Bertics, S.J., Seymour, W.M. and Shaver, R.D. (2003) Lactation performance by dairy cows fed supplemental biotin and a B-vitamin blend. Journal of Dairy Science, 86, 2106-2112. doi:10.3168/jds.S0022-0302(03)73800-4

[13] Santschi, D.E., Berthiaume, R., Matte, J.J., Mustafa, A.F. and Girard, C.L. (2005) Fate of supplemental B-vitamins in the gastrointestinal tract of dairy cows. Journal of Dairy Science, 88, 2043-2054. doi:10.3168/jds.S0022-0302(05)72881-2 